\title{
Quality Control of Tramadol in Kisangani: Development, Validation, and Application of a UV-Vis Spectroscopic Method
}

\author{
Marguerite Borive Amani ${ }^{*}$, Jérémie Mbinze Kindenge ${ }^{2}$, Emile Tweni Baruti ${ }^{1}$, \\ Elodie Nsasi Bakiantima ${ }^{1}$, Salomon Batina Agasa ${ }^{3}$, Philippe Hubert ${ }^{4}$, \\ Roland Marini Djang'eing'a',4
}

\begin{abstract}
${ }^{1}$ Department of Pharmacy, Faculty of Medicine and Pharmacy, University of Kisangani, Kisangani, Democratic Republic of the Congo ${ }^{2}$ Laboratory of Drugs Analysis, Department of Galenic and Drug Analysis, Faculty of Pharmaceutical Sciences, University of Kinshasa, Kinshasa, Democratic Republic of the Congo

${ }^{3}$ Department of Internal Medicine, Faculty of Medicine and Pharmacy, University of Kisangani, Kinshasa, Democratic Republic of the Congo

${ }^{4}$ Laboratory of Analytical Pharmaceutical Chemistry, Faculty of Medicine, University of Liège, Liège, Belgium Email: ${ }^{\star}$ maguyborive@gmail.com, ${ }^{\star}$ marguerite.borive@unikis.ac.cd
\end{abstract}

How to cite this paper: Borive, M.A., Kindenge, J.M., Baruti, E.T., Bakiantima, E.N., Agasa, S.B., Hubert, P. and Djang'eing'a, R.M. (2021) Quality Control of Tramadol in Kisangani: Development, Validation, and Application of a UV-Vis Spectroscopic Method. American Journal of Analytical Chemistry, 12, 295-309.

https://doi.org/10.4236/ajac.2021.128018

Received: August 10, 2021

Accepted: September 7, 2021

Published: September 10, 2021

Copyright $\odot 2021$ by author(s) and Scientific Research Publishing Inc. This work is licensed under the Creative Commons Attribution International License (CC BY 4.0).

http://creativecommons.org/licenses/by/4.0/ (c) (i) Open Access

\begin{abstract}
Context: Substandard and falsified medicines are circulating in low-income countries mostly without any control. We availed a simple and not expensive UV-Vis spectroscopic method to evaluate the quality of tramadol in Kisangani before and during the Covid-19 period. Methods: For the analytical quantitative method, an experimental design was applied to set up the optimal levels of the selected factors, namely, $\mathrm{pH}$ of dissolution medium, type of cuvette, and wavelength. Taking into account the capsule pharmaceutical formulation within $80-120 \mu \mathrm{g} \cdot \mathrm{mL}^{-1}$ concentration range, we analyzed 89 tramadol samples from pharmacies and hospitals of the six Kisangani municipalities. Results: $\mathrm{pH}$ showed a significant effect on absorbance, whereas quartz cuvette and wavelength did not. A typical $100 \mu \mathrm{g} \cdot \mathrm{mL}^{-1}$ tramadol solution gave an absorbance of 0.64 at $272 \mathrm{~nm}$. Validation highlighted a matrix effect observed with a $6 \%$ bias. A correction factor of 0.9372 allowed to improve the accuracy profile, which were then totally included within the $10 \%$ acceptance limits. Quality control revealed that 25 samples out of 89 were not compliant in terms of manufacturing license, registration status in DRC and content as well. Conclusion: This study showed that the strengthening of analytical strategy in Kisangani is a need.
\end{abstract}

\section{Keywords}

Tramadol, UV-Vis Spectroscopy, Method Development, Validation, Quality 


\section{Introduction}

The illicit traffic of medicines is expanding at global and local levels that constitute a criminal activity against which many countries fight against depending on the means [1] [2]. The United States Pharmacopoeia has an estimated proportion of falsified drugs at more than $10 \%$ of the global market [3], however, this proportion can be higher in developing countries and particularly where the control is weak [4] [5] [6]. The illicit traffic has several consequences on public health (such as therapeutic failure, increasing of the intake doses by the patient because of therapeutic ineffectiveness, etc.) and on the socioeconomic that leads to impoverishment of the population because of their penetration into the legal supply chain [7] [8]. There is a need for appropriate solutions to consolidate the worldwide initiatives [9] [10] [11] [12]. In West Africa, the development of landbased pharmacies for the illicit sale of fixed point or outpatient drugs has made the misuse of psychotropic products among young people [13] [14]. The phenomenon was also reported with tramadol, a centrally acting analgesic with multimode action including several clinical uses [15] [16] [17]. In the Democratic Republic of the Congo (DRC), some people are using it in mixture with local alcoholic drinks such as called "lotoko" (in Lingala, a DRC common language) for unknown health reasons but most probably for a well-being effect additionally to the analgesic effect [18]. Several health professionals noticed it as a painkiller of choice, particularly for patients suffering from sickle cell disease [19], such as Kisangani where the prevalence of this disease is among the highest (around 23\%) [20] [21]. However, tramadol is abused almost everywhere with repeated intoxication cases that necessitate its dosage in biological fluid that needs more complex analytical methods [22] [23]. These later are not possible to carry out in several laboratories in the DRC due to the lack of suitable equipment. Most of them use alternative methods dedicated to raw materials that need more samples and thus not appropriate to analyze low dosage formulations such as capsules [24] [25]. In this work, we applied a simple and rapid UV-Vis spectroscopy method to control the quality of tramadol capsules marketed in Kisangani and particularly during the Covid-19 period because of it high consumption [26]. Prior this routine application, the developed method was submitted to a validation stage using the total accuracy profile strategy to guarantee future reliable results. Routine analyses included also other quality parameters.

\section{Materials and Methods}

\subsection{Chemicals and Reagents}

The following were obtained from Aldrich (St Louis, MO, USA): Tramadol Hydrochloride (99\%), Kollidon (100\%), Methylhydroxypropyl cellulose purity unknown, Microcrystalline cellulose purity unknown, (Avicel PH-101 $50 \mu \mathrm{g}$ ). Col- 
loidal dioxide silicon (99.9\%) (Aerosil 200, Pharma) was obtained from Aerolub (Chaumont-en-Vexin, France), magnesium stearate (99\%) from ADC Chemistry (Chateauneuf du Rhone, France), hydrogen phosphate of calcium (99.9\%), Croscamellose sodium and starch purity unknown, from Avebe (Courcouronnes, France), lactose (99\%) from Meggle Pharma Excipients \& Technology (Wasserburg, Germany). MilliQ water was obtained from the Milli-Q plus purification device (Millipore, Billerica, MA, USA). All other chemicals used for the experiments were of analytical grade. The samples of tramadol capsules were procured from several pharmacies from different Kisangani municipalities and from hospital pharmacies.

\subsection{Apparatus}

Two UV-Visible spectrophotometers were used, the Perkin Elmer Lamda 40 UVVis (Waltham, Massachusetts, USA) for the development and validation of the method performed in Liège (Belgium), and Shimadzu UV-Vis(Kyoto, Japan) for the routine analyses done at Kisangani (DRC).

\subsection{Analytical conditions}

The UV-Vis spectrophotometry method was developed on basis of the physico-chemical data of tramadol using a simple experimental design and taking into account the pharmaceutical formulation [27] (See Figure 1).

\subsection{Preparation of Solutions}

\subsubsection{Solutions for Experimental Design}

In a $100.0 \mathrm{~mL}$ volumetric flask was introduced $100.0 \mathrm{mg}$ of tramadol CRS, then dissolved with milli-Q water. Further dilution was done with the same diluent to obtain seven concentration levels: 150, 120, 100, 80, 50, 40 et $20 \mu \mathrm{g} \cdot \mathrm{mL}^{-1}$. Two other preparations were repeated using $100 \mathrm{mM} \mathrm{HCl}$ and $100 \mathrm{mM} \mathrm{NaOH}$, respectively. These three sets of solutions were used to select the appropriate solvent and the optimal concentration level corresponding to the appropriate absorbance.

\subsubsection{Solutions for Validation}

\section{1) Calibration standards}

In a $100.0 \mathrm{~mL}$ volumetric flask was introduced $100.0 \mathrm{mg}$ of tramadol CRS which was dissolved using $100 \mathrm{mM} \mathrm{HCl}$ to obtain a stock solution. Three solutions at three concentration levels $\left(80,100\right.$ and $\left.120 \mu \mathrm{g} \cdot \mathrm{mL}^{-1}\right)$ were prepared by suitable

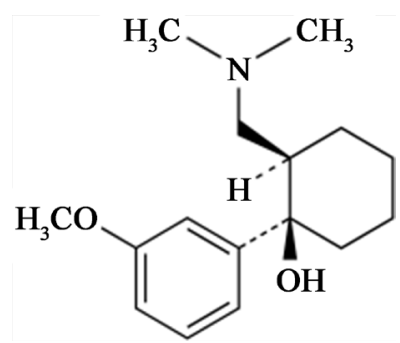

Figure 1. Chemical formula of tramadol: $\mathrm{C}_{16} \mathrm{H}_{25} \mathrm{NO}_{2}$, Molecular Weight: $263.4 \mathrm{~g} / \mathrm{mole}$; pKa: 8.3 and 9.4; easily soluble in water and in ethanol. 
dilution from the stock solution and to allow drawing the calibration. The overall preparation was repeated for two additional days corresponding to three days.

2) Validation standards

In a $100.0 \mathrm{~mL}$ volumetric flask was introduced $100.0 \mathrm{mg}$ of tramadol CRS and about $285 \mathrm{mg}$ of the excipient mix which were dissolved using $100 \mathrm{mM} \mathrm{HCl}$ to obtain a stock reconstituted solution. Sonication was needed for $10 \mathrm{~min}$ to ensure the dissolution of tramadol.

Three working solutions at five concentration levels $(80,90,100,110$ and 120 $\mu \mathrm{g} \cdot \mathrm{mL}^{-1}$ ) were prepared by suitable dilution from the stock solution using the same solvent. They were filtered using a $0.45 \mu \mathrm{m}$ Whatman paper filter. The overall preparation was repeated in two additional days corresponding to three days ( $p=3$ series and $n=3$ repetitions). The excipient mix was composed with kollidon (3.818 gr), silicon dioxide colloidal (0.127 gr), magnesium stearate (0.076 gr), methylhydroxypropyl cellulose (2.163gr), calcium hydrogen phosphate (1.578 gr), microcrystalline cellulose $(0.661 \mathrm{gr})$, sodium croscarmellose $(0.061 \mathrm{gr})$, starch (1.000 gr) and lactose (0.578 gr).

Working temperature: ambient temperature $\left(25^{\circ} \mathrm{C}\right)$ storage temperature of stock solutions: 2 to 8 degrees (Refreigerator).

\subsubsection{Solutions Used for the Assay}

At ambient temperature $\left(25^{\circ} \mathrm{C}\right)$, the test sample solutions were prepared as following: weigh a corresponding amount of $50 \mathrm{mg}$ of tramadol, then dissolve with $100 \mathrm{mM} \mathrm{HCl}$ and dilute ten times with milli-Q water. The working solutions were filtered prior to reading using UV-Vis spectroscopy.

\subsection{Sample Collection for Quality Control and Sample Coding}

\subsubsection{Sample Collection}

The sampling of tramadol samples was targeted within the six municipalities of Kisangani city (Kabondo, Tshopo, Makiso, Mangobo, Kisangani, and Lubunga) in public pharmacies and in hospital pharmacies as well. The inclusion criteria were: capsule or tablet formulations, monotherapy, whereas exclusion criteria were the formulation with two or more active pharmaceutical ingredients such as tramadol with another analgesic or anti-inflammatory, or other pharmaceutical formulations. The metadata obtained as schematized in Figure 2 were encoded using Excel file for Windows version 16. The theoretical sample size $(N)$ was calculated considering the general formula of sampling size (see Equation (1)) [28].

$$
N=p(1-p) z^{2} / E^{2}
$$

where $p$ is the prevalence, $z$ is the confidence interval, and $E$ is the margin of error with $95 \%$ confidence interval. An investigation team was set up including one principle supervisor and four investigators. The role of the principle investigator was the contact with the authorities at the political, administrative, and health levels, whereas the investigators have to collect the samples as mystery shoppers. Supervisors and investigators must have a medical background, speaking local 


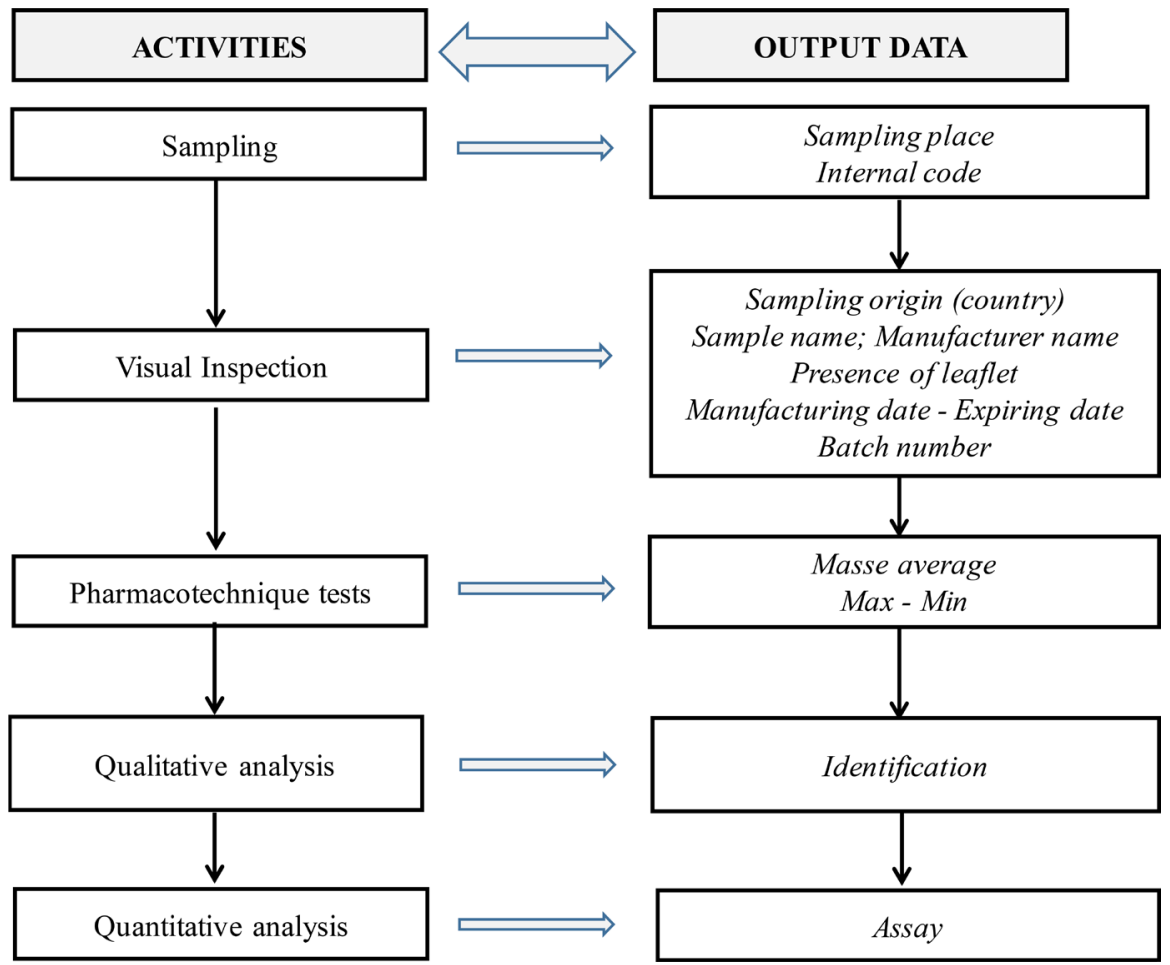

Figure 2. Sampling strategy (scheme and analyses).

language (Lingala or Swahili) to simulate the users.

\subsubsection{Database for Quality Control}

To allow us doing also a survey of quality control, we collected the following data entries: 1) sampling places including the geographical sampling location, administrative and health sectors, 2) the findings of visual inspection including country of origin, sample trade name, manufacturer name and license status in DRC [29], shelf life, presence of leaflet, 3) the findings of physico-chemical tests including mass deviation, excipient content per capsule, identification and assay of API using our developed method. We tried to classify as much as possible those findings according to unusual and abnormal outcomes.

\subsection{Software}

The Design expert 11 (Statease, Minneapolis, MN, USA) was used to draw for the experimental design and for the statistical calculation related to the method optimization. For the validation step, the accuracy profiles as well as statistical calculations including the validation results and different uncertainty estimates were obtained using the Enoval ${ }^{\circledR}$ V3.0 software (Pharmalex, Mont-saint Guibert, Belgium).

\section{Results and Discussion}

\subsection{Results}

\subsubsection{Method Development}

We selected two quantitative factors ( $\mathrm{pH}$ or $X_{1}$ and wavelength or $X_{2}$ ) and one 
qualitative factor (type of bowl or $X_{3}$ ) to be tested with respect to the experiment levels indicated in Table 1 . The selected analytical response was the absorbance $(Y)$. A full factorial composite was selected and elaborated to design the experimental plan whose experiences where randomly performed with twelve runs as shown in Table 2. The main linear effects $\left(b_{1}, b_{2}\right.$, and $\left.b_{3}\right)$, the quadratic terms $\left(b_{11}\right)$, and the first-order interactions $\left(b_{12}\right.$ and $\left.b_{13}\right)$ of the factors were evaluated in the models [see Equation (2)].

$$
Y=b_{0}+b_{1} X_{1}+b_{2} X_{2}+b_{3} X_{3}+b_{11} X_{1}^{2}+b_{12} X_{1} X_{2}+b_{13} X_{1} X_{3}
$$

When the $\mathrm{pH}$ is increased (alkaline value), the absorbance decreases but remains still acceptable. More over with the bowl, we noticed a decrease of the absorbance for the glass bowls. The fitted model estimates the mean effect of the bowl, the linear effects of the length and $\mathrm{pH}$, a quadratic effect for $\mathrm{pH}$, an interaction effect between the wavelength and the cuvette, and the interaction between the linear effect of $\mathrm{pH}$ and the bowl.

As can be seen in Figure 3, the absorption of tramadol in the ultraviolet zone was higher at the acidic medium ( $\mathrm{pH}$ mostly between 0.3 to 3.0) at a wavelength from $270 \mathrm{~nm}$ to $272 \mathrm{~nm}$ and in the quartz bowl. The statistical treatment confirmed that the $\mathrm{pH}$ and the type of cuvette affect the absorbance of tramadol in

Table 1. Experimental domain.

\begin{tabular}{ccccc}
\hline & & Level (-1) & Level (0) & Level (+1) \\
\hline \multirow{2}{*}{ Quantitative factors } & pH of solution; $\mathrm{X}_{1}$ & 0.3 & 6.6 & 12.0 \\
& Wavelength; $\mathrm{X}_{2}$ & $270 \mathrm{~nm}$ & - & $272 \mathrm{~nm}$ \\
Qualitative factors & Type of bowl; $\mathrm{X}_{3}$ & Quartz & - & Glass \\
\hline
\end{tabular}

Table 2. Experimental matrix.

\begin{tabular}{|c|c|c|c|}
\hline \multirow{2}{*}{ Run ordering } & \multicolumn{3}{|c|}{ Factors } \\
\hline & $\mathrm{X}_{1}$ & $\mathrm{X}_{2}$ & $\mathrm{X}_{3}$ \\
\hline 1 & -1 & -1 & -1 \\
\hline 2 & 0 & -1 & -1 \\
\hline 3 & +1 & -1 & -1 \\
\hline 4 & -1 & +1 & -1 \\
\hline 5 & 0 & +1 & -1 \\
\hline 6 & +1 & +1 & -1 \\
\hline 7 & -1 & -1 & +1 \\
\hline 8 & 0 & -1 & +1 \\
\hline 9 & +1 & -1 & +1 \\
\hline 10 & -1 & +1 & +1 \\
\hline 11 & 0 & +1 & +1 \\
\hline 12 & +1 & +1 & +1 \\
\hline
\end{tabular}




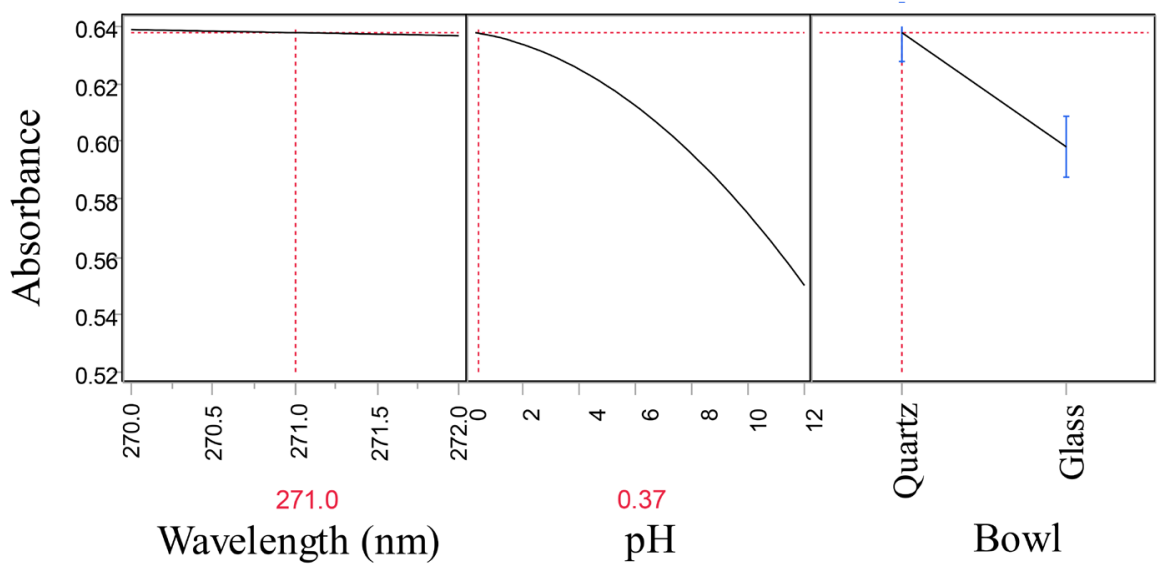

Figure 3. Effects of factors.

Table 3. Statistical significance $\left(P\right.$ Value $\left.{ }^{\star}\right)$ of the coefficients of the model for each response.

\begin{tabular}{ccc}
\hline Sources & $F$ & Prob $>F^{*}$ \\
\hline $\mathrm{X}_{1}[0.3-12]$ & 312.8572 & $<0.0001$ \\
$\mathrm{X}_{2}[270-272]$ & 0.5665 & 0.4855 \\
$X_{1}^{2}$ & 20.8996 & 0.0060 \\
$\mathrm{X}_{3}$ & 66.7251 & 0.0014 \\
$\mathrm{X}_{2} \times \mathrm{X}_{3}$ & 0.0354 & 0.8590 \\
$\mathrm{X}_{1} \times \mathrm{X}_{3}$ & 6.2464 & 0.0540 \\
\hline
\end{tabular}

${ }^{\star}$ The significant values at the $5 \%$ level are printed in bold-face type.

the ultraviolet zone compared to other factors.

The interaction between the $\mathrm{pH}$ and the type of bowl was also significant. Hence, Quartz is the best bowl to use. Indeed, the effect of $\mathrm{pH}$ is significant as well as that of the bowl type effect (see Table 3).

\subsubsection{Method Validation}

This step was assessed by applying the total error strategy that takes into account the accuracy profile as a decision tool. It is built considering the acceptance limit which allows the analyst to make decisions based on the objective of the analytical method [30]. Therefore, the method is declared valid when the beta-expectation tolerance intervals are within those accepted acceptance limits, here $10 \%$. We considered a risk of $5 \%$. For the evaluation of the matrix effect, we took into account both capsule and tablet composition.

From the experiment data (concentration values and areas) of the calibration standards, we constructed several regression models in which the validation standards (areas) were fitted to obtain back-calculated concentrations, which then allow to draw several accuracy profiles. Only the linear regression model gave an acceptable accuracy profile within the acceptance limits (Figure 4(a)).

However, we noticed an overall bias of about $6 \%$ at all concentration levels 

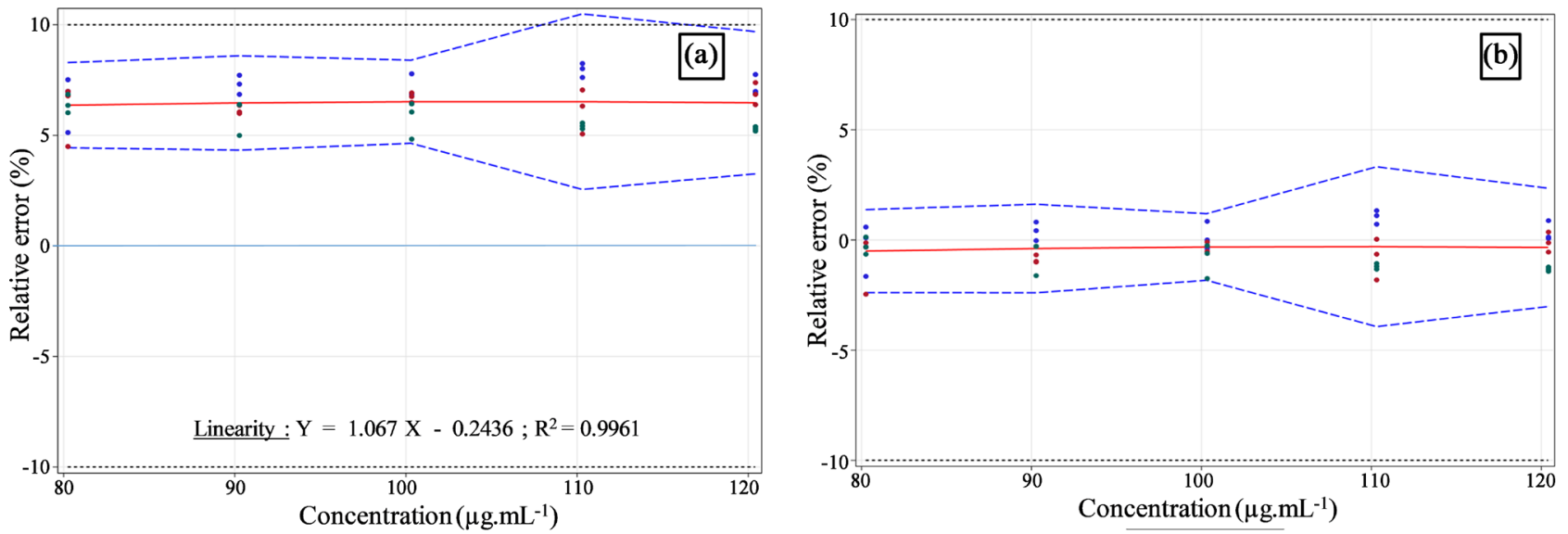

Figure 4. Accuracy profiles before (a) and after (b) applying a correction factor.

that may lead to high consumer and producer risks in routine analyses. We investigated the cause by mean of the root cause analysis which revealed that this systematic error is due to the matrix effect. Thus, we had to apply a correction factor (CF) (Equation (3)) to all results.

$$
\mathrm{CF}=1 / \text { slope }=1 / 1.067=0.9372
$$

Therefore, an appropriate accuracy profile was constructed (Figure 4(b)) with the beta-expectation tolerance intervals included within the acceptance limits that demonstrate the adequacy of the method to furnish reliable and accurate results. The validation results summarized in Table 4 demonstrated a suitable method trueness with absolute relative biases below $0.51 \%$, a suitable precision with relative standard deviation values below $1.29 \%$, an excellent linearity between the introduced concentrations and back-calculated ones, adequate lower and upper quantitation limits with suitable detection limit.

For the routine analysis of tramadol capsules, we applied Equation (3) from Beer-Lambert law to allow the quantitation of as follows:

$$
\text { Concentration obtained }=A /[\mathcal{E} \times l]
$$

With $A$ the absorbance of a $0.1 \mathrm{mg} \cdot \mathrm{mL}^{-1}, I$ the length of the bowl that is, $1 \mathrm{~cm}$ and $\mathcal{E}$ the molar absorptivity or molar extinction coefficient which was calculated to be $\mathcal{E}=1535$. Then we draw the accuracy profile of the obtained results which was similar with the previous accuracy profile.

\subsubsection{Routine Analyses}

1) Sample collection

The targeted sample size $(N)$ was 89 samples calculated considering the general formula of sampling size (see Equation (1)), with an estimated range of $12 \%$ - $48 \%$ poor-quality medicine, a proportion of $34 \%$ in the parent population that would be a realistic premise and a precision of $10 \%$ [31]. Thanks to the mystery shoppers, we were able to achieve this sample size of tramadol capsules. As can be seen in Table 5, the samples were taken mostly from private sector and from pharmacy. Due to the difficult of accessibility, only 7 samples were collected in 
Table 4. Trueness and precision of the corrected method.

\begin{tabular}{cccc}
\hline \multirow{2}{*}{$\begin{array}{c}\text { Concentration } \\
\text { level }(\mu \mathrm{g} / \mathrm{mL})\end{array}$} & $\begin{array}{c}\text { Relative bias } \\
(\%)\end{array}$ & $\begin{array}{c}\text { Repeatability } \\
\text { (RSD \%) }\end{array}$ & $\begin{array}{c}\text { Intermediate precision } \\
(\text { RSD \%) }\end{array}$ \\
\cline { 2 - 4 } 80.0 & -0.51 & 0.96 & 0.97 \\
90.0 & -0.39 & 0.51 & 0.81 \\
100.0 & -0.32 & 0.60 & 0.71 \\
110.0 & -0.30 & 0.58 & 1.29 \\
120.0 & -0.34 & 0.37 & 0.92 \\
Linearity: $Y=1.000 X-0.3801$ & & & \\
$R^{2}=0.9964$ & & \\
Limit of detection (LOD) $=3.621 \mu \mathrm{\mu g} / \mathrm{mL}$ & & \\
Lower limit of quantitation (LLOQ): $80.24 \mu \mathrm{g} / \mathrm{mL}$ & & \\
Upper limit of quantitation (ULOQ): $120.40 \mu \mathrm{g} / \mathrm{mL}$ & & \\
\hline
\end{tabular}

Table 5. Outcomes of quality survey.

\begin{tabular}{|c|c|c|c|}
\hline & \multicolumn{3}{|c|}{ Number of samples } \\
\hline \multirow[t]{6}{*}{ Location sampling place } & Mak $=$ Makiso & 24 & \\
\hline & $\mathrm{Kab}=$ Kabondo & 18 & \\
\hline & Kis $=$ Kisangani & 14 & \\
\hline & Man $=$ Mangobo & 14 & \\
\hline & $\mathrm{Tsh}=\mathrm{Tshopo}$ & 12 & \\
\hline & Lub = Lubunga & 7 & \\
\hline \multirow[t]{2}{*}{ Administrative sector } & Private & 85 & \\
\hline & Public & 4 & \\
\hline \multirow[t]{3}{*}{ Health sector } & Pharmacy & 65 & \\
\hline & Health Center & 20 & \\
\hline & Hospital & 4 & \\
\hline \multicolumn{4}{|l|}{ Findings of visual inspection } \\
\hline \multirow[t]{5}{*}{ Country of origin } & India & 44 & \\
\hline & DRC & 24 & \\
\hline & Uganda & 17 & \\
\hline & Nepal & 2 & \\
\hline & Unknown & 2 & \\
\hline \multirow[t]{4}{*}{ Sample trade name } & Tramadol & 7 & Yes \\
\hline & Tradol & 6 & Yes \\
\hline & Tramazac & 35 & Not registered \\
\hline & Tramadon & 20 & Not registered \\
\hline
\end{tabular}




\begin{tabular}{|c|c|c|c|c|}
\hline & Tramaren & 16 & \multicolumn{2}{|l|}{ Not registered } \\
\hline & Nemadol & 2 & \multicolumn{2}{|l|}{ Not registered } \\
\hline & T-Dol & 1 & \multicolumn{2}{|l|}{ Not registered } \\
\hline & Agitram & 1 & \multicolumn{2}{|l|}{ Not registered } \\
\hline & Tramazem-5 & 1 & \multicolumn{2}{|l|}{ Not registered } \\
\hline \multirow{10}{*}{$\begin{array}{c}\text { Manufacturer/Distributor } \\
\text { located in DRC }\end{array}$} & Cadila Health care & 35 & \multicolumn{2}{|l|}{ Yes } \\
\hline & Phatkin & 20 & \multicolumn{2}{|l|}{ Yes } \\
\hline & Prince Pharma & 6 & \multicolumn{2}{|l|}{ Yes } \\
\hline & Caisa Pharma & 5 & \multicolumn{2}{|l|}{ Yes } \\
\hline & Congo Pharma SARL & 1 & \multicolumn{2}{|l|}{ Yes } \\
\hline & Pharma plus SARL & 1 & \multicolumn{2}{|l|}{ Yes } \\
\hline & Taluka industrie & 1 & \multicolumn{2}{|l|}{ Yes } \\
\hline & Rene Industries & 16 & \multicolumn{2}{|l|}{ No } \\
\hline & National Health care & 2 & No & Found in Uganda \\
\hline & National Pharm Biosa & 2 & No & \\
\hline \multirow{2}{*}{$\begin{array}{l}\text { Manufacturer } \\
\text { licenced in DRC }\end{array}$} & Yes & \multicolumn{3}{|l|}{7} \\
\hline & No & \multicolumn{3}{|l|}{3} \\
\hline \multirow[t]{3}{*}{ Shelf life } & $>3$ years $=$ Acceptable & \multicolumn{3}{|l|}{6} \\
\hline & $<3$ years $=$ Suspicious & \multicolumn{3}{|l|}{57} \\
\hline & No data $=$ unacceptable & \multicolumn{3}{|l|}{26} \\
\hline \multirow[t]{2}{*}{ Presence of leaflet } & Yes & \multirow{2}{*}{\multicolumn{3}{|c|}{ No information available }} \\
\hline & No & & & \\
\hline
\end{tabular}

Findings of physico-chemical tests

\begin{tabular}{ccc} 
Mass deviation & $\leq 10 \%=$ Conform & 63 \\
& $>10 \%=$ Non conform & 26 \\
\hline $\begin{array}{c}\text { Excipient content } \\
\text { per gelule }\end{array}$ & $<4$ times = Acceptable & 42 \\
& $4-6$ times = Suspicious & 26 \\
& $>6$ times = Abnormal & 21 \\
\hline Assay of API & $90 \%-110 \%$ : Conform & 65 \\
& $<90 \%$ : Underdosage & 15 \\
& $>110 \%$ : Overdosage & 9 \\
\hline
\end{tabular}

the Lubunga municipality that is located the other side of Congo River.

2) Findings of visual inspection,

The majority (about half) of the samples were from India, one of the largest drug producers in the world, $27.0 \%$ from DRC, and 19.1\% from Uganda, the nearest eastern country. Surprisingly, 2 samples were from Nepal, uncommon country cooperation to DRC, and 2 samples were even of unknown origin, that is, non-conformity. 
On the other hand, a very high proportion (85.4\%) of samples were not registered in DRC with $14.6 \%$, that is, non-conformity too. This seems to be abnormal since $77.5 \%$ of the manufacturers are located in DRC while the remaining were located in Uganda, we often meet medicines without any marketing authorization, whereas others lose their authorization because of no renewal while their products are still in the market. Another situation encountered is that the producers do have the local distributor authorization for foreign pharmaceutical producers. Concerning the shelf life, we found abnormal that only 6 samples out of 89 (or 6.7\%) did have acceptable duration, whereas 57 samples (or 64.0\%) had below three years of duration and even no available data for 26 samples (29.2\%). None sample did have leaflet information.

\section{3) Findings of physico-chemical tests}

About the mass deviation, 63 samples (or 70.7\%) had acceptable variations that were less than $10 \%$ against 26 (or $29.2 \%$ ), which were greater, expecting a problem with the sample manufacturing. Concerning the excipient content per capsule, only 42 samples (or 47.2\%) were less than four times the total mass that seems usual and acceptable. However, 26 samples (or 29.2\%) were suspicious and 21 samples (or 23.6\%) were abnormal since the excipient contents were more than six times. This indicated again a manufacturing problem. Prior to their assay, all 89 samples were compliant in terms of tramadol identification, with 65 samples for which the tramadol content were conform, 15 samples with under-dosage, and 9 samples with over-dosage.

\subsection{Discussion}

When seeking for our data, we could not find any tendency between the findings of physico-chemical tests and visual inspection or sampling meaning that those findings are randomly observed all over Kisangani and affected all its municipalities depending on the sampling size.

The multitude of drugs containing tramadol and of trade marks in Kisangani municipality in one hand, and the existence of some samples without manufacturing license or not registered in DRC in another hand, can be explained by the porosity of the border with the nearest eastern countries such as Uganda with whom there are economical exchange including the pharmaceutical. This constitutes one of the causes of circulation of substandard drugs in DRC for which similar findings were obtained by Kalenda et al. [32]. It can be noticed that other drugs come from Kinshasa, but their qualities are also affected.

The existence of under-dose tramadol samples during this period of coronavirus pandemic may be explained by the fact that being a painkiller, the falsifiers expect to make great benefit because this drug would be in great demand to treat the symptoms of Covid-19 that may lead to addiction in the sickle cell patient as reported by Sy [26] [33]. Moreover, the existence of tramadol overdose would explain the measurement described in West African countries to cope with the strong heat of the day [13]. The side effects of tramadol [34] may be observed 
mainly with motorcycle taximan who are the main consumers in Kisangani due to overload daily work.

\section{Conclusions}

To the best of our knowledge, this study is the first to have an interest in the development and validation method for quality control of tramadol in Kisangani. This substance in capsule and tablet forms can be assayed by UV-Visible spectroscopy at $272 \mathrm{~nm}$ using acidified water as the dissolving solvent and a quartz cuvette which were the best analytical conditions. The method was proven during a successful validation step using a total error approach for which the accuracy profile demonstrated the suitability of the method. Then out of 89 samples collected in Kisangani, several situations found for non-conformity revealed the necessity to sustain the quality control of tramadol samples. Indeed, this study highlighted that tramadol is also subject to falsification as for other lifesaving medicine antibiotics, antimalarial.

The weakness of our study is that it is based on a non-separative method, which cannot measure tramadol in combinations and cannot measure degradation impurities. In perspective, we will validate the method on the injectable matrix for use to measure tramadol in injectable solutions which are widely used in hospitals.

\section{Authors' Statements}

\section{Authors' Contributions}

MBA and RMD contributed to the study conception and overall design.

RMD coordinated the overall study from conception to the final manuscript.

$\mathrm{PH}$ and JMK supervised the development of the method and manuscript review.

RMD supervised validation of the method.

SBA supervised sample collection contributed to manuscript review and provided with study authorization.

ENB and ETB conducted sample collection and performed their control quality.

\section{Acknowledgements}

This work was done with the financial support of the Academy of Research and Higher Education is the Federation of French-speaking higher education institutions in Belgium (ARES). We thank the coordination team of PFS-2016 project (Ph. Hubert and P. Takaisi Kikuni) and PRD-2018 project (R. Marini Djang'eing'a and S. Batina Agasa).

The students' mystery shoppers (Kisembo, Bangoza, Ohemba Adingo, and Ossinga Zalimbo) and C. Waffo (for some data treatments) are thanked.

\section{Ethical Approval}

The authors declare that all data are original and have not been submitted else- 
where.

\section{Conflicts of Interest}

The authors declare no conflicts of interest regarding the publication of this paper.

\section{References}

[1] Delval, P. (2016) Tramadol ou Captagon: L’Afrique sous amphétamine? Financial Afrik.

https://www.financialafrik.com/2016/08/08/tramadol-ou-captagon-lafrique-sous-a mphetamine

[2] United Nations Office on Drugs and Crime (UNODC). World Drug Report 2016. Vienna. https://www.unodc.org/doc/wdr2016/WORLD DRUG REPORT 2016 web.pdf

[3] United States Pharmacopoeia Global Public Policy Position. Combatting Substandard and Falsified Medicines.

https://www.usp.org/sites/default/files/usp/document/about/public-policy/combatti ng-substandard-and-falsified-medicines-policy-position.pdf

[4] Nayyar, G.M., Breman, J.G., Newton, P.N., et al. (2012) Poor-Quality Antimalarial Drugs in Southeast Asia and Sub-Saharan Africa. The Lancet Infectious Diseases, 12, 488-496. https://doi.org/10.1016/S1473-3099(12)70064-6

[5] The Editorial Board (2015, May 18) Stemming the Tide of Fake Medicines. The New York Times, A18. http://nyti.ms/1GiM4r6

[6] Breman, J.G. (2018) Eliminating Poor Quality Medicines: "Caveat Emptor, Caveat Venditor” (Buyer Beware, Seller Beware). International Health, 10, 321-323.

https://doi.org/10.1093/inthealth/ihy051

[7] Ozawa, S., Deson, G., Bessias, S., et al. (2019) Modeling the Economic Impact of Substandard and Falsified Antimalarials in the Democratic Republic of the Congo. American Journal of Tropical Medicine and Hygiene, 100, 1149-1157. https://doi.org/10.4269/ajtmh.18-0334

[8] Mackey, T.K., Liang, B.A., York, P., et al. (2015) Counterfeit Drug Penetration into Global Legitimate Medicine Supply Chains: A Global Assessment, 2015. American Journal of Tropical Medicine and Hygiene, 92, 59-67.

https://doi.org/10.4269/ajtmh.14-0389

[9] Newton, P.N., Tabernero, P., Dwivedi, P., et al. (2014) Falsified Medicines in Africa: All Talk, No Action. The Lancet Global Health, 2, 509-510. https://doi.org/10.1016/S2214-109X(14)70279-7

[10] Herrington, J.M., Nayyar, G.M.L., et al. (2015) The Global Pandemic of Falsified Medicines: Laboratory and Field Innovations, Policies and Perspectives. American Journal of Tropical Medicine and Hygiene, 92, 1-136. https://doi.org/10.4269/ajtmh.15-0221

[11] Newton, P.N. and Bond, K.C. (2019) Global Access to Quality-Assured Medical Products: The Oxford Statement and Call to Action. The Lancet Global Health, 7, e1609-e1611.

[12] Newton, P.N. and Bond, K.C. (2020) COVID-19 and Risks to the Supply and Quality of Tests, Drugs, and Vaccines. The Lancet, 8, e754-e755. https://doi.org/10.1016/S2214-109X(20)30136-4 
[13] Maiga, D.M., Houdou, S., et al. (2012) Misuse of Tramadol by Adolescents and Young Adults in Street Situations. The Pan African Medical Journal, 13, 45.

[14] Machado-Alba, J.E., et al. (2020) Use of Tramadol or Other Analgesics in Patients Treated in the Emergency Department as a Risk Factor for Opioid Use. Pain Research and Management, 2020, Article ID: 8847777.

https://doi.org/10.1155/2020/8847777

[15] Eldemrdash, A.M. and Abdelzaam, E.M. (2018) Continuous Intra-Articular Ropivacaine/Tramadol Combination Infusion Therapy Improves Postoperative Outcome of Total Knee Arthroplasty. Open Journal of Anesthesiology, 8, 137-146. https://doi.org/10.4236/ojanes.2018.85015

[16] El-Gerby, Y.M., El-Sholkamy, M.A., Abdelhai, A.F., et al. (2015) The Effect of Tramadol Hydrochloride Intraarticular Injection on IL-6 Level in Patients with Tempromandibular Joint Internal Derangement. Pain Studies and Treatment, 3, 31-37. https://doi.org/10.4236/pst.2015.34004

[17] Machado-Alba, J.E., Serna-Echeverri, L.S., Valladales-Restrepo, L.F., et al. (2020) Use of Tramadol or Other Analgesics in Patients Treated in the Emergency Department as a Risk Factor for Opioid Use. Pain Research and Management, 2020, Article ID: 8847777. https://doi.org/10.1155/2020/8847777

[18] Osman, M. and Mustafa, M. (2018) Tramadol-Induced Mood Elevation in a Patient with No Previous Psychiatric History. Case Reports in Psychiatry, 2018, Article ID: 9574395. https://doi.org/10.1155/2018/9574395

[19] George, I.O. and Aiyedun, C.N. (2015) Acute Chest Syndrome in Children with Sickle Cell Anaemia: An Audit in Port Harcourt, Nigeria. Open Journal of Pediatrics, 5, 320 325. https://doi.org/10.4236/ojped.2015.54048

[20] Batina-Agasa, S., et al. (2010) Prevalence of Sickle Cell Disease in a Northeastern Region of the Democratic Republic of Congo: What Impact on Transfusion Policy? Transfusion Medicine, 20, 62-65. https://doi.org/10.1111/j.1365-3148.2009.00943.x

[21] Neema-Ufoy, M.Y., et al. (2020) Performance of Sickle SCAN ${ }^{\circledR}$ in the Screening of Sickle Cell Disease in Kisangani Pregnant Women and Attitude towards Results. Open Journal of Blood Diseases, 10, 23-36. https://doi.org/10.4236/ojbd.2020.102003

[22] Zhang, C.Y., Liu, T., Zhang, X.L. and Liu, E.B. (2013) Determination of Tramadol in Human Serum by Capillary Electrophoresis with the End-Column Electrochemiluminescence Detection. Open Journal of Biophysics, 3, 121-127. https://doi.org/10.4236/ojbiphy.2013.32015

[23] Nagaraju, P., et al. (2018) LC-MS/MS Quantification of Tramadol and Gabapentin Utilizing Solid Phase Extraction. International Journal of Analytical Chemistry, 2018, Article ID: 1605950. https://doi.org/10.1155/2018/1605950

[24] Yao, X., Zhang, J. and Li, J. (2011) Flow Injection Determination of Tramadol Based on Its Sensitizing Effect on the Chemiluminescent Reaction of Permanganate-Sulfite. American Journal of Analytical Chemistry, 2, 768-775. https://doi.org/10.4236/ajac.2011.27088

[25] Vinay, K.B., et al. (2012) A Stability Indicating UPLC Method for the Determination of Tramadol Hydrochloride: Application to Pharmaceutical Analysis. Chromatography Research International, 2012, Article ID: 870951. https://doi.org/10.1155/2012/870951

[26] Radbruch, L., et al. (2020) The Key Role of Palliative Care in Response to the COVID19 Tsunami of Suffering. The Lancet, 395, 1467-1469.

https://doi.org/10.1016/S0140-6736(20)30964-8 
[27] Nabais, T. and Leclair, G. (2014) High-Amylose Sodium Carboxymethyl Starch Matrices: Development and Characterization of Tramadol Hydrochloride Sustained-Release Tablets for Oral Administration. ISRN Pharmaceutics, 2014, Article ID: 391523. https://doi.org/10.1155/2014/391523

[28] Mavungu, D.J., et al. (2020) Quality of Antimalarials in Kinshasa Peri-Urban Areas with Regard to Local Pharmaceutical Legislation and Regulation. International Health, 12, 253-263. https://doi.org/10.1093/inthealth/ihz070

[29] Direction de la Pharmacie et du Médicament (DMP), Secrétariat Général à la Santé, Ministère de la Santé Publique, République Démocratique du Congo (2020) Répertoire des Produits Pharmaceutiques enregistrés et autorisés par la DPM en République Démocratique du Congo, Edition 2020, November.

https://acorep-dpmrdc.org/Base/GetPDF/22?filename=Re\%CC\%81pertoire\%20des \%20produits\%20pharmaceutiques $\% 20$ enregistre $\%$ CC $\% 81$ s $\% 20$ et $\% 20$ autorise $\%$ CC \%81s\%20par\%20la\%20DPM\%20en\%20RDC\%2C\%20Edition\%202020\%20\%281\%29 .pdf

[30] Hubert, Ph., et al. (2004) Harmonization of Strategies for the Validation of Quantitative Analytical Procedures: A SFSTP Proposal-Part I. Journal of Pharmaceutical and Biomedical Analysis, 36, 579-586. https://doi.org/10.1016/S0731-7085(04)00329-2

[31] Schiavetti, B., et al. (2018) The Quality of Medicines Used in Children and Supplied by Private Pharmaceutical Wholesalers in Kinshasa, Democratic Republic of Congo. A Prospective Survey. American Journal of Tropical Medicine and Hygiene, 98, 894903. https://doi.org/10.4269/ajtmh.17-0732

[32] Kalenda, et al. (2018) Investigation of the Quality of Antibiotics-Based Amoxicillin for Monitoring of Some Different Medicine Markets of Democratic Republic of Congo. American Journal of Analytical Chemistry, 9, 366-385.

[33] Sy, A., et al. (2020) Sickle Cell Patient and Addiction to Tramadol: Case Management in Senegal. Health, 12, 99-105. https://doi.org/10.4236/health.2020.122008

[34] Kyung, C.S., et al. (2019) Opioid Analgesics Are the Leading Cause of Adverse Drug Reactions in the Obstetric Population in South Korea. Medicine, 98, 21. https://doi.org/10.1097/MD.0000000000015756 